\title{
ESKATOLOGIESE PERSPEKTIEWE IN DIE NAGMAAL
}

\author{
P.W. Bingle \\ J.J. van der Walt \\ Departement Diaknniologie \\ Potchefstronmse Universiteit vir Christelike Hoër Onderwys \\ POTCHEFSTROOM
}

\author{
Abstrad \\ ESCHA TOLOGICAL PERSPECTMES IN HOLY COMMUNION
}

Eschatolog reveals various perspectives conceming Holy Communion. Formulation, definition and the context of Holy Communion in the Scriptures have an eschatological setting. Due to the dovetailing of the old and the new aeon Hohy Communion contains an eschatological tension; it projects an eschatological prefiguration; there is an eschatological solidity and adherence in Hoby Communion, namely, the God of faith; an eschatological maturing process takes place in and through Holy Communion; there is an eschatological dimension with an existential moment in Holy Communion; there is an eschatological paranese in Hohy Communion; eschatology pmojects an alignment with the judgement of God into Hoby Communion and eschatology places Holy Communion in a missiological perspective. The remembrance of the perfecte fulfilled by Christ invokes the futura which is yet to come. The commemonative chanacter of Holy Communion is more than a mere in memoriam of Christ's death as Mediator. It is a remembrance of Jesus Chrish, the risen Lord Himself By virue of its sacramental nature, Holy Communion as a nemembrance supper is a eoken and seal of the body and blood of the Mediator lesus Christ the Lond - He who is the Eschatos will come as the Elpidos for time and etemity. This sacromental token and seal is also token and seal of the final eschaton when God will be all in all (cf I Cor 15:28).

\section{INLEIDING}

Die sakramente doop en Nagmaal staan afgeëts teen die horison van die eskaton. In gehoorsaamheid aan die opdrag van die Here Jesus met sy hemelvaart "om alles te onderhou wat Ek julle beveel het" (Matt 28:20), sal en moet en mag die kerk tot aan die voleinding die doop bedien en die Nagmaal vier. Hoewel beide sakramente die volbragte werk van Christus die Middelaar beklemtoon, is dit nie minder 'n eskatologiese prefigurasie na die groot en finale dag waarvan die belofte spreek en wat naby ons kom in die werklike teenwoordigheid van Christus self - praesentia realis Christi ipsius - hier en nou (vgl. Calvyn, 1986:680; Van der Walt, 1976:49). Die koninkryk is in die Persoon, Woord en werk van Jesus Christus reeds teenwoordige werklikheid. So is die sakramente eskatologiese merkers en tekens, opgerig en bedien russen die tye, tussen koms en wederkoms van Christus. Dit is tekens en seëls dat die reële (lineêre) 
tyd ook Christus-Zeit is (Schulze, 1982:142); dit is: relasionele tyd, gevulde tyd (vgl. Snyman, 1977:183)

\section{ESKATOLOGIESE BEGRIPSBEPALING}

Onder die term eskatologie word nie verstaan 'n veraf futurum waarin die mens momenteel hier en nou nie betrokke is nie. Die eskatologiese toekoms behoort nie tot die terrein van die terra incognita waartoe ons konkluderende kennis nie kan deurdring nie: die verborge dinge (vgl. Berkouwer, 1961:7). Die eskaton is nie net iets toekomstigs nie. Dit is nie 'n vreemde iets wat in die verte verwag word nie. Die eskaton staan nie net aan die eindpunt van die lineêre tyd nie. Dit dring die empiriese bestaan van hierdie bedeling binne. In die mens se onderweg wees staan die mens onder 'n eskatologiese voorbehoud: ad personam is dit afgeslote, ad opera is dit nog onvolledig. Daarom, elke Woord- en sakramentbediening "must reflect something of the eschatological tension of the dispensation, as the dispensation of the last days" (Verhoef, 1973:26).

\section{ESKATOLOGIESE FORMULERING, DEFINIëRING EN KONTEKS VAN DIE NAGMAAL}

Direkte Skrifgegewens rondom die Nagmaal is relatief min. Allerweë word erken dat, as dit nie was vir die misbruike in Korinte wat die aanleiding was tot Paulus se vermanings (vgl. 1 Kor 10 en 11) nie, ons waarskynlik nie eers sou geweet het dat die vroeë kerk wel die Nagmaal gevier het nie (vgl. Smit, 1984:11).

In die viering van die Nagmaal is veral drie aspekte te onderskei: die aspek van gedenk, van verkondiging en van verwagting. Die verwagtingsmoment is die eskatologiese perspektief in en van die Nagmaal. Hoe wesenlik die verwagtingsaspek tot die viering van die Nagmaal behoort, laat alle Nuwe Testamentiese berigte met betrekking tot die instelling van die Nagmaal blyk. Aan die eintlike instelingswoorde word deur Jesus toegevoeg (vgl. Matt 26:29) dat $\mathrm{Hy}$ vanaf daardie moment nie meer van die vrug van die wynstok sou drink nie "tot op die dag wanneer Ek saam met julle die nuwe wyn in die koninkryk van my Vader sal drink". Markus (14:25) se formulering korrespondeer sterk met die van Matteus, terwyl Lukas twee maal die versekering van Jesus gee dat die viering van die Nagmaal die perspektief open op die komende maaltyd in die koninkryk van God (vgl. Luk 22:16 en 18). By Paulus kom die eskatologiese aspek aan die orde in die woorde "totdat Hy kom", ná sy uitspraak oor die verkondiging van die dood van die Here so dikwels die brood geëet en uit die beker gedrink word (vgl. 1 Kor 11:26). 
Dit is 'n legitieme vraag of die eskatologiese perspektief nie te veel ontbreek of onderspeel word in die Nagmaalsformulier nie. Van 't Spijker (vgl. 1980:417) gee toe dat so 'n vraag nie ten onregte is nie, maar voeg daaraan toe "laat men niet vergeten, dat al Gods weldaden beginnen met het wondere geloof: ik geloof de vergeving der zonden. In de vergeving zijn alle andere zegeningen ingevouwen. En wie de vergeving gelooft en daarom aanvaardt en ervaart vindt ook al die andere goedere met Christus." Dus, indien nie eksplisiet nie dan wel implisiet, is die eskatologiese perspektief sterk ingebed in die onderbou van die Nagmaalsformulier.

\section{ISKATOLOGIES-POL ARE SPANNING IN DIE NAGMAAL}

Op verskeie wyses kom die eskatologiese perspektief by die viering van die Nagmaal in die gesigskring. Allereers mag by die viering van die Nagmaal gesmaak en geproe word dat in Christus die nuwe verbond gerealiseer en die heilstyd aangebreek het. Die eskatologiese perspektief in die Nagmaal word belig vanuit die sentrale tekenspraak wat dui op die eenmalige offer van Christus. Vanuit hierdie beseëling in Christus is die Nagmaal die voorgereg van die feesmaal in die vervulde koninkryk van God. "Bij brood en beker mogen wij weten, dat de toekomst niet meer onzeker is. De toekomst is aan Christus, omdat in Hem die toekomst al heden geworden is." (Versteeg, 1980:63.) Hierdie eskatologiese perspektief gee 'n blydskapskarakter aan die Nagmaalsviering. Die maaltyd in die oudste Christelike gemeente, dié van Jerusalem, was ook met blydskap gevier (vgl. Handelinge 2:46).

Tegelyk word by die viering van die Nagmaal besef dat die voleinding nog nie gekom het nie. Die seismologiese trillings van die "in elkaar grijpen" (Ridderbos, 1966:50) van die aeon breek nog deur. Hierdie polariteit, hierdie kontinuïteit en diskontinuïteit roep spanning op in hierdie gebroke bedeling. Die verkondiging van die genade wat in die Nagmaal opgesluit lê asook die eskatologiese hoop, gaan in teen die grein van die natuurlike orde. Dit word nie geëkstrapoleer vanuit 'n natuurlike orde nie, maar vanuit 'n ander orde, naamlik 'n eskatologiese orde (vgl. Louw, 1984:41). Hierdie hoopvolle verkondiging roep vanweë sy aard spanning en konflik op. Dit open 'n nuwe - vir die wèreld 'n vreemde en ongelooflike - perspektief wat diametraal teenoor die werklikheid staan en tog die werklikheid diapositief/transparant deurskou ten opsigte van sy wese, naamlik nuwe skepping. Die eskatologiese perspektief roep dus die bede om die wederkoms op. Dit is die roep om die definitiewe en finale koms van die Here in heerlikheid - maranata (1 Kor 16:27).

Hierdie wesenskou het in die "hoogspanningsdraden der eschatologie" (Haitjema, 1956:3) in die hede 'n pneumatologiese karakter wat deur Paulus só omskrywe word: 
"Want ons verwag deur die Gees uit die geloof die geregtigheid waarop ons hoop" (Gal 5:5). Die Nagmaalsformulier formuleer die pneumatologies-eskatologiese snypunt/inbreekpunt van die nuwe aeon in die ou aeon s6: "Waar ons egter deur die genade van die Heilige Gees oor sulke gebreke van harte berou het en opreg begeer om volgens die gebooie van God te lewe." Die werk van die Heilige Gees in die Nagmaal is dus "niet (maar) een aanhangsel, een pro memorie post" nie (Van 't Spijker, 1980:405).

\section{ESKATOLOGIESE PREFIGURASIE IN DIE NAGMAAL}

Alhoewel die Nagmaal kragtens sy seëlkarakter beseëling is van die volbragte werk van Christus, is daar kragtens sy tekenkarakter nog 'n onafheid en 'n onvoltooidheid. Sakramente is maar nog net tekens, prefigurasie. Dit is nog die verwagting as onthulling van die vervulling. "The eucharist falls short of the final kingdom, because it is a periodic and not a perpetual celebration" (Wainwright, 1978:120.) Daar is in die Nagmaal 'n totdat ... . Wat in die Nagmaal "deur die geloof ontvang word", laat uitsien en heenroep na wat in die toekoms sal kom. So gaan in die Nagmaalsviering die vensters oop na die toekoms - 'n oopheid en 'n openheid na die "volle betekenis" (Luk 22:16). Daarom is die Nagmaal ook middel en nie doel nie, nie eindpunt en arriveerpunt nie. Dit is manna onderweg na die deurlugtige en finale dag wat kom. Nagmaal is, soos ook die Christelike doop, eskatologiese teken en sein wat in hierdie gebroke bedeling heenwys en heenroep na die voltooiing van hierdie bedeling en die volmaakte wat kom. (Die eskatologiese perspektief vrywaar dan ook teen sakramentalisme.)

Die hede en die toekoms kan nie hermeties van die verlede afgesluit word nie (vgl. Van der Walt, 1962:312) en is onlosmaaklik aan mekaar verbind in Christus wat die Eskatos is. In Christus, die Eskatos, is die eskaton reeds hier, maar in Christus, omdat Hy ook nog weer kom, is die eskaton ook nog toekomstig. Begin en ontwikkeling, tyd en tydsverloop, speel wel 'n rol, maar 'n ondergeskikte rol. Die dimensie is meer as bloot net 'n lineere tydslyn. Kwalitatief beweeg die eskaton in Christus, die ewige Logos, reeds op die lineêre tydslyn (vgl. Bingle, 1988:130-142).

Daar is dus 'n sterk element van eskatologiese hoop in die Nagmaal ingebou, maar dan nie 'n hoop wat alles net verplaas na die toekoms as ' $n$ vae silhoeët of skimagtige voorafskaduwing van wat nog moet kom nie. Die Christelike hoop wat die Nagmaal verkondig , moenie so verkondig word - en God só met die hoop identifiseer - dat sy synswyse bloot as die inhoud en grond van die hoop gesien word nie. So 'n synswyse (God as die Komende) sou daarop neerkom dat Hy niks anders en meer as komende is nie. Dan gaan die teologie op in eskatologie (vgl. Louw, 1984:23). Dan word die seëlkarak- 
ter van die sakrament eskatologie verplaas na die eindpunt van die tyd. Die hede is nie 'n hede "waarbij de hoogspanningsdraden der eschatologie stroomloos zijn geworden" (Haitjema, 1956:3). Dit is 'n hede waarin die konflik van die aeone-wisseling uitgeworstel word.

God het sy finale heilsdaad begin - sigbaar en hoorbaar - op 'n allesoortreffende wyse. Maar so oorweldigend as wat hierdie begin is, so duidelik is dit ook maar nog net ' begin. En dan is dit menslik logies dat wat begin is, ook voltooi sal word, want dit is Gód wat die einde begin bewerk het en niks kan Hom keer nie. Teenoor die mens se logies staan egter God se teologies: Hy skuif as ' $t$ ware met 'n magtige hand die logiese aansluiting van die Voleinding terug, en maak ruimte (vgl. Van der Walt, 1962:311) ruimte vir die dek van die tafel van die gemeenskapsmaal. Hy reël alles, en so oorweldigend is sy reeds dat dit ook die nog nie kan trotseer totdat Hy ook dit vul.

Die onafheid van die Nagmaal is ook daarin geleë dat die Goddelike glorie nie sigbaar teenwoordig is in die viering nie. Wat gesien word by die viering is sondaars, nie baie wys, nie baie magtig ... en wat nie meer doen as om ' $n$ broodjic te eet en wyn te neem met danksegging nie. Hierdie beperking en onvoltooidheid moet egter nie in 'n negatiewe sin verstaan word nie, want hulle wat in opregtheid die Nagmaal vier, "lewe deur geloof, nie deur sien nie" (2 Kor 5:7); "[hulle] kyk nog in 'n dowwe spieël en sien 'n raaiselagtige beeld" (1 Kor 13:12).

Die in-gedagtenis-bring karakter van die Nagmaal is daarom mér as 'n gedagtenis aan Christus se Middelaarsdond. Dit is 'n gedagtenis aan Christus Jesus self. Jesus het gesê: "Gebruik dit tot my gedagtenis" (1 Kor 11:24,25).

Dit word algemeen aanvaar dat $̇ \mu o \zeta$ hier 'n objektiewe genitief verteenwoordig (vgl. Wainwright, 1978:178; Jeremias, 1960:242). Dit is Christus self wat in gedagtenis gebring moet word. En hoewel sy eenmalige offer volmaak was, is Christus nie volledig in alles wat Hy met sy eerste koms gedoen het nie. Hy is ook die Een wat was en weer kom. "It is because the eucharist is a memorial of the one and the same Christ who has come and who is to come that the anamnesis of the anaphoras can remember all the saving dispensation for us, from thy conception, birth and holy baptism, thy saving passion, thy life-giving death, thy three day's burial, thy glorious resurrection, thy ascension into heaven and thy sitting at the right hand of God the Father, and thy dreadful advent ... (Wainwright, 1978:67). Juis in die gedagtenis-karakter kom die toekomsperspektief na vore.

So is daar wisselwerking tussen verlede en toekoms in die hede. Die gedagtenis aan of die in-gedagtenis-bring van die perfecta wat Christus gedoen het en aangebring het, roep juis ook die futura van wat nog kom, op. 


\section{ESKATOLOGIESE VASTE PUNT EN VASHOUPUNT IN DIE NAGMAAL: DIE GOD VAN TROU}

Die sakrament van die Nagmaal is die versekering en teken dat Christus "die nuwe en ewige testament, die verbond van die genade en versoening bevestig het toe Hy gesê het: dit is volbring" (Nagmaalsformulier). God se trou en alles wat Hy Hom van ewigheid af voorgeneem het na sy verkiesende welbehae, word as 't ware saamgetrek in die woord genadeverbond. Die nuwe, beter verbond is die samevatting van die volle heil van God in Christus, in sy ryke en heerlike vervulling, vergewing, vernuwing, verheerliking en ewige lewe. In die Nagmaal word die deelhê aan die verbond beteken en verseël.

Die Nagmaal is dus "veel meer dan een akte van de herinnering, die vol betrokkenheid in het verleden verwijlt. Het is een daad van het geloof, waardoor dat verleden herleeft, meer nog, waardoor Christus ons nabij komt" (Van 't Spijker, 1980:402). Die Nagmaal is 'n akte van Christus self. Hy oorhandig aan die syne 'n goddelike waarborg van sy liefde en trou.

Fundamenteel in die Nagmaal vanuit sy eskatologiese gerigtheid is die gewaarborgde belofte van God se trou "geprojekteerd op het scherm van de toekomst" (Berkhof, 1968:16). God se trou aan Homself en aan sy beloftes fundeer die hoop wat in die Nagmaal verkondig word en waarin geleef mag word. Dit bepaal die kwaliteit van die hoop vir hede en toekoms. "Sie kann nicht eine gute oder eine böse Hoffnung sein, sondern sie ist stets eine gute Hoffnung, die mit Vertrauen und Glauben das Gute, ja das Heil schlechthin erwartet." (Bardtke, 1959:415.)

God se trou is dus die vaste punt, vashoupunt en begronding van die Nagmaal. Die hoop waarvan die Nagmaal verkondiging is, is kragtens die trou van God gewaarborgde hoop. Die toekoms is in God se hand, reeds in die hede van sy trou. Die verkondiging wat van die Nagmaal uitgaan, is die vervulling van 'n toekoms wat gewaarborg is in die trou van God. "Maaltyd der hoop wordt zo de dis van het verbond. Het geloof wordt versterkt. De liefde wordt gevoed. Maar niet het minst wordt ook de verwachting gewekt, en het uitzien naar het bruiloftsmaal dat komt." (Van 't Spijker, 1980:410.)

Die trou van God gee aan die sakrament sy seëlkarakter. Sou dit sterker verwoord kon word as in die teken van gebreekte brood en van die vergote wyn met die gepaardgaande $E k$ vir julle? "Dit verseker Ek julle: As julle nie die liggaam van die Seun van die mens eet en sy bloed drink nie, het julle nie die lewe in julle nie. Wie my liggaam eet en my bloed drink, het die ewige lewe, en Ek sal hom op die laaste dag uit die dood laat opstaan. My liggaam is die ware voedsel, en my bloed is die ware drank" 
(Joh 6:53-55.)

\section{ESKATOLOGIESE RYPING IN EN DEUR DIE NAGMAAL}

Kragtens die trou van God en die waarborg in Christus verseker die Nagmaal dat die gelowige nou, in die hede reeds, in die ewige lewe staan. Hierin kom die eskatologiese opvoedingsperspektief van die Nagmaal na vore. Dit dui in die rigting van die meditatio vitae futurae. Die geloof kan in sy volledige betrokkenheid op die toekomende onsterflikheid onder die term eskatosentries tuisgebring word. Die eskatosentrisiteit van die geloof is die kontinue lewensrigting van die onsterflike mens, wat die mens oproep om hom "van ganser harte in te span om oor die toekomstige lewe na te dink" (Calvyn, 1988:913)

Hierdie meditatio vitae futurae is nie 'n blote mediterende godsdiensoefening waarby die lewenspraktyk nie inbegrepe is nie. Dit is ' $n$ religieuse koers vol ondernemende geloofsaktiwiteit en ontvouende geloofsvisie ten opsigte van die deur sonde gebroke werklikheid in en rondom hom. "Meditatio vitae futurae is nothing other than hopeful faith itself which directs its confidence to the Christ of God who has brought us eternal life and will at some future date disclose its full glory. The man who stands firm in the meditatio vitae futurae, lives here in this world already the life of eternity in proportion as he dies to life on earth." (Quistorp, 1955:49.)

Die Nagmaal werk dus 'n eskatologiese ryping in die hand. "Ons moet onthou dat niemand goeie vordering in Christus se skool kan maak tensy hy die dag van sy dood en die laaste opstanding met blydskap afwag nie." (Calvyn, 1988:917.) Dit is dan ook die kenmerk en die teken waarin die Nagmaal gevier word, naamlik dat die gelowige uitsien na " die gelukkige dag wat ons verwag" (Tit 2:13). "Nou wag die oorwinnaarskroon vir my, die lewe by God [coram Deo]. Op die dag dat Hy weer kom, sal die Here, die regverdige Regter, dit vir my gee, en nie net vir my nie, maar ook vir almal wat met verlange uitsien na sy koms" (2 Tim 4:8.)

\section{ESKATOLOGIESE DIMENSIE EN SY EKSISTENSIēLE MOMENT IN DIE NAGMAAL}

Nagmaal vanuit die eskatologiese dimensie tref die mens in sy huidige eksistensie, met 'n antisipasie op sy toekomstige eksistensie. Christus, die opgestane Here wat in die Nagmaal verkondig word, is self die waarborg dat die Nagmaal nie 'n in memoriam getuienis is nie, maar aktuele, eksistensiële getuienis van die lewende God wat al die 
getuienis waar maak totdat Hy weer kom (vgl. Van der Walt, 1988:220). Eweneens laat die verkondiging van die Christelike hoop die Nagmaalsviering nie verloop en afloop in teoretiese en intellektualistiese wetenswaardighede oor die toekoms waarin die mens nie eksisteer nie. Dit is juis die verkondiging van 'n toekoms waarin die mens ten volle betrokke is. Dit kom aan op ervaring in die openbaringsomgang van God met die kommunikant. Ervaring in hierdie sin is "ein lebendiger, beständig, fortschreitender Wachtsumsprozess, in dem immer wieder neue Erfahrungen gemacht und innerlich angeeignet werden" (Bollnow, 1970:136).

'n Essensiële kenmerk van die ervaringsproses van geloof, hoop en liefde is die openheid daarvan. Hoop is nie gekristalliseer en gegiet in ' $n$ vasstaande vorm nie. Hoop is oop - open ended - en daarom nie staties nie, maar dinamies. Dit is hoop-inwording, hoop-in-ryping. Dit is ervaring-in-wording, ervaring onderweg. As viator in die interimtyd - dit is die Nagmaalsbedeling - word die gelowige nooit volledig mens van ervaring nie. Dit is heel die lewe, tot die laaste toe, 'n saak van hoe langer hoe meer (vgl. Heidelbergse Kategismus, antwoord 89). Deur ervaring wys geword, word die gelowige steeds meer 'n kind wat 'n toekoms vol misterie en belofte tegemoet sien. Die eksistensie in die hede word vir hom steeds meer 'n interim en "eschatology is the hope of things to come with a large margin of unheard - of novelty which transcends experience and imagination" (Firet, 1975:215). "Die lewe is soos 'n wagpos waarin die Here ons geplaas het, en ons moet dit oppas totdat Hy ons terugroep." (Calvyn, 1988:916.) Hierdie eskatologiese wagpos is meer as 'n wagkamer. Dit is 'n weg, 'n eskatologiese weg waarop God met die mens op weg is.

\section{ESKATOLOGIES-GEORIËNTEERDE PARANESE IN DIE NAGMAAL}

Die dinamiese openheid en oproep tot nie-gearriveerdheid en geloofsgroei kom sterk na vore in die paranetiese gedeelte van die Nagmaalsformulier, veral in die derde hoofpunt van selfondersoek: "... van nou af met sy hele lewe ware dankbaarheid aan God te betoon ... en voortaan in ware liefde en eensgesindheid met sy naaste te lewe." Ook "dat ons daagliks moet stry teen die swakheid van ons geloof en ons sondige drifte". Die paranese is gerig op die nog nie in die lewe van die gelowige. Die nuwe aeon het reeds gekom maar is nog oorvleuelend met die ou aeon. Vanuit die eskatologiese dimensie is die Nagmaalsviering deel van 'n voortdurende proses in die geloofsgroei van die gelowige.

Hiermee is die Nagmaalsformulier in lyn met die paranetiese aard van die Skrif. So byvoorbeeld is die inhoud van die paranese in Romeine 13:11-14 deurgaans verwoord in die aoristos (met die uitsondering van vers $14 \mathrm{~b}$ waar die praesens gebruik word). Die gebruik van die aoristos beklemtoon die eskatologiese karakter van die paranese. 
'n Besondere nuanse word hiermee aan die betekenis en inhoud van die paranese gegee. "Dit kan so gestel word: Nou - in die nuwe aeon: maak vir julleself die saak uit en begin finaal om die werke van die duisternis af te lè; die wapens van die lig aan te trek; te wandel soos in die lig; julle te beklee met die Here Jesus - en moet dan nooit weer (vs 14b - praesens) voorsorg tref vir die begeertes van die vlees nie." (Venter, 1985:110.)

\section{ESKATOLOGIE RIG NAGMAAL OP DIE OORDEEL VAN GOD}

As profesie van die koms van Christus die Eskatos, is die Nagmaal ook 'n profesie van die eindgerig. Die Nagmaal is nie net genadeverkondiging nie. Nagmaal is ook gerigsverkondiging. Ook in die oordeelskarakter wat ten grondslag van die Nagmaal lê, is 'n eskatologiese dimensie. "The sacramental coming of the Lord always sets men in the perspective of the Last Day and therefore itself bears the marks of what God will do at the Last Day. It is a kind of anticipation, within the church, of the Last Day." (Käsemann, 1960:25.)

Teenswoordig is die eksegetiese konsensus rondom die onwaardige deelname en die gepaardgaande oordeel, die sogenaamde manducatio indignorum, dat dit gaan om 'n persoonlike teenwoordigheid van Christus, die Here, nou reeds in die Nagmaal, wat sowel vergifnis as oordeel beteken (vgl. Smit, 1984:30).

Nie alleen in die moment van Nagmaalsviering vind 'n oordeel plaas nie. Oordeel vind plaas reeds in die wyse waarop die mens respondeer wanneer hy met Christus gekonfronteer word (vgl. Joh 3:18; 5:24). Daar is reeds "nou geen veroordeling vir dié wat in Christus Jesus is nie" (Rom 8:1). "Iemand wat aan Christus behoort is 'n nuwe mens." (2 Kor 5:17.) Dit is helaas so dat diegene wat Nagmaal vier, sondaars is wat in praktyk hulle aanvaarde vryspraak repudieer. "The eucharist is a repeated projection of the last judgement which each time partly fulfils, and therefore strengthens, the promise of judgement and pardon which we received in hope in our baptism." (Wainwright, 1978:80.)

Die sterkste Skrifbewys in diê verband is 1 Korintiërs 11:27-34. Paulus skryf hier in dekrete taal, in juridiese en naasjuridiese terme, en wel in verband met

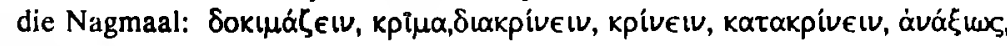
Ěvoxoc. Paulus is duidelik daaroor dat die Nagmaal die middel (in die kerk van Korinte altans) geword het van oordeel. Daarom waarsku hy: "Elkeen wat op 'n ongepaste wyse van die brood eet of uit die beker van die Here drink, sal skuldig wees aan sonde teen die liggaam en die bloed van die Here" en: "hy wat eet en drink sonder om te besef dat dit die liggaam van die Here is, bring daar- 
deur 'n oordeel oor homself" (1 Kor 11:27,29). Paulus se gedagtegang beweeg van die eskatologiese toekoms (ëvoxos ëotaı vers 27) na die feit dat die Korintiërs alreeds in die hede 'n oordeel oor hulleself eet en drink ( 1 Kor 11:29-31). Daarom is die selfondersoek van wesenlike belang (vers 28 ). Wat op die laaste dag geopenbaar sal word, is in die sakrament in 'n sekere sin reeds 'n realiteit "Anliegen und Eigenart..." (Kảsemann, 1960:23).

In elke Nagmaal word die wederkoms van Christus bely. En Christus, die Here, is beide Saligmaker én Regter. Deur onwaardige gebruik van die Nagmaal "we cannot paralyse God's eschatological action" (Kasemann, 1960:25). Christus se teenwoordigheid laat die mens nooit ongeaffekteerd nie. Dit lê nie by die kommunikant om die oordeel uit te skakel of te kanselleer deur die liggaam van Christus nie te onderskei nie. Die oordeel is onontvlugbaar. Die oordeel is 'n "begeleidingsverschijnsel" (Floor, 1979:131) van God se verlossing. Die sakramentele koms van die Here stel die mens in die perspektief van die Laaste Dag en dra daarom self die merktekens van wat God in die Laaste Dag sal doen. Nagmaal is 'n antisipasie van die Laaste Dag. Die laaste oordeel sal niks minder wees as approbasie of ratifikasie van die evangelie nie.

Ofskoon die afwassing van sondes en die vryspraak in Christus sakramenteel reeds in die doop gegee is, is die mens steeds geneig tot die sonde. Daarom moet die Christen in die interim tussen doop en die laaste oordeel homsef ondersock (1 Kor 11:28) om nie onder die oordeel te kom nie (vers 31) en om nie 'n oordeel oor homself te eet en te drink deur skuldig te wees aan sonde teen die liggaam en die bloed van die Here nie (vers 27), en ons saam met die wêreld veroordeel word (vers 32). "The Christian is at every eucharist required to renew his baptismal acceptance of the divine condemnation on sin." (Wainwright, 1978:83.)

Die Nagmaal is vanuit eskatologiese perspektief dus 'n genadige tugtiging (tugmeester) ( $\pi \alpha \delta € v o ́ \mu \epsilon \theta \alpha$, vers 32a), met die doel om ons tot selfondersoek en skuldbelydenis te bring en ons te red van die finale eindoordeel (vers 32b). Ook in die beker-woorde of bloed-woorde ... "tot vergewing van sondes" (Matt $26: 28$ ) is ' $n$ ondertoon van die oordeel waarvan vrygespreek word. Die Nagmaal bied dus nie net eksplisiet 'n perspektief op die dood van Christus nie, maar ook tot sy wederkoms, soos Jesus die stel: "Ek sé vir julle: Van nou af sal Ek nie weer van hierdie wyn drink nie tot op die dag wanneer ek saam met julle die nuwe wyn in die koninkryk van my Vader sal drink." (Matt 26:29.) Nagmaal is dus 'n eskatologiese teken en 'n eskatologiese alarm (vgl. Bingle, 1988:372-378); "it is a throwing forward Christ's final advent into the present ... into man's present experience" (Wainwright, 1978:92). So is die koms of teenwoordigheid van Christus in die Nagmaal 'n projeksie van sy finale koms, 'n belofte van wat sal wees na genade én oordeel. 


\section{ESKATOIOGIE PLAAS NAGMAAL IN MISSIOLOGIESE PERSPEKTIEF}

Die Nagmaal het ongetwyfeld 'n onontwykbare en ongetwyfelde missiologiese karakter. Nagmaal het 'n "onbegrensde reikwydte; die teken van die vergewing en die aanbod van die nuwe heilsplan is missionêr gerig op die nasies" (Muller, 1984:69). Nagmaal is ' $n$ eskatologiese teken van die groot fees wat God in die finale van sy koninkryk bring om uitdrukking te gee aan sy universele oorwinning. Daarvan profeteer Jesaja (25:6-9): "Op hierdie berg gaan die Here die Almagtige 'n feesmaal gereed maak vir al die volke ..." Veral by Markus en Matteus val die klem op die geweldige waarheid: die evangelie is oop vir almal, vir die nasies, vir elkeen wat glo. Jesus gee die versekering: "Baie sal van die ooste en die weste af kom en saam met Abraham, Isak en Jakob aan tafel gaan in die koninkryk van die hemel." (Matt 8:11; vgl. Luk 13:29.)

Die teken van die Nagmaal is op die eskatologiese reis van die kerk deur die wêreld 'n teken vir die nasies sodat gegryp en gereik mag word na die belofte van hoop en dat so reeds 'n voorsmaak ontvang mag word van die koninkryk wat reeds sakramenteel in die hede geprojekteer is.

Hierdie missiologiese dimensie wat die eskatologie aan die Nagmaal gee, het ekklesiologiese konsekwensies. Die kerk moet, hierdeur versterk en aangespreek, reageer in die wete dat dit God se wil is dat soveel as moontlik vergader moet word om in die geloof reeds deel te hê aan die maal wat die teken is van die bruilofsfees. Hierby moet onthou word dat die Nagmaal middel is, nie doel nie. Meer as middel is die Nagmaal nie. (Wainwright (1978:130) wys daarop, en nie sonder meriete nie, dat die kerk in sy sending en evangeliserende funksie daarop aandring om in te kom "sodat my huis vol kan word" (Luk 14:23), maar dat wanneer hulle binne is, geen voedsel en drank wat die teken is van die groot feesmaal van die koninkryk, gegee word nie. En dit terwyl "every celebration of the Lord's supper is a sign erected of the coming great banquet, and God wishes His house to be full" (Wainwright, 1978:131).

Op voetspoor hiervan pleit sommige vir 'n oop Nagmaal, met verwysing na byvoorbeeld Handelinge 27:33-38 waar Paulus aan heidense skipbreukelinge

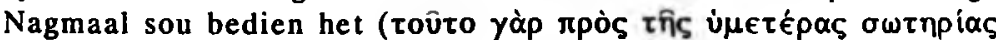
intó́pxesvers 34). Hierby moet egter onthou word dat die eerste sakramentele moment van respons op die verkondiging van die evangelie normaalweg die doop is. Die kerk moet dus onderskei tussen die sakramente. Toetrede tot die teken-oprigting-gemeenskap van die kerk is deur die doop.

Hoewel die kerk van Christus 'n oop kerk is en die Woord en sakramente nie in die geheim of in isolasie bedien word nie, is dit 'n sinvolle vraag of die coram publico-ka- 
rakter sterk genoeg figureer (vgl. Wainwright, 1978:134) en of die profetiese getuienis wat vanuit die Nagmaalsviering moet uitgaan, liturgies nie meer tot sy reg kan kom nie.

Met bogenoemde in gedagte, kom die vraag na vore of kerkgeboue nie liturgies en argitektonies so ontwerp moet word nie dat die coram-publico-karakter van die Nagmaal (en prediking) meer tot sy reg kan kom. Die beginsel is tog dat Woord- en sakramentsbediening nie 'n geheime handeling is nie. Die Nagmaal is ' $n$ teken van die koninkryk van God met 'n appèl op die hele wêreld. Die evangelies maak dit duidelik dat Jesus sy tekens in die openbaar gedoen het. Dit was deel van 'n bediening wat die aankondiging was van die koninkryk van God en 'n uitnodiging om die koninkryk van God in te gaan. "The church must hope and expect that through the words and actions of the eucharistic sign which it performs before the world, God will arouse in those who have not so far committed themselves to His kingdom the desire to share in the blessing of salvation." (Wainwright, 1978:134.)

\section{SLOTSOM}

Die gedagtenis aan of die in-gedagtenis-bring van die perfecta wat Christus gedoen het en aangebring het, roep ook die futura van wat nog kom, op. Die in-gedagtenis-bring karakter van die Nagmaal is daarom mér as 'n gedagtenis aan Christus se Middelaarsdood, mér as ' $\mathrm{n}$ in memoriam. Dit is 'n gedagtenis aan Christus self - $\mathrm{Hy}$ wat is en wat was en wat kom (vgl. Op 1:4). Jesus het gesê: "... gebruik dit tot my gedagtenis" (1 Kor 11:24,25.) Kragtens sy wese as sakrament is die Nagmaal as gedagtenismaal teken en seël van die liggaam en bloed van die Middelaar, Jesus Christus die opgestane Here Hy wat die Eskatos is en weer kom as die Elpidos vir tyd en ewigheid. Hierdie sakramentele teken en seël is ook eskatologiese teken en seël van die finale eskaton wanneer God alles sal wees vir alles (vgl. 1 Kor 15:28).

\section{BIBLIOGRAFIE}

BARDTKE, H. 1954 Hofnung im alten Testament. Die Religion in Geschichte und Gegenwart. Teil III. Tubingen : Mohr.

BERKHOF, H. 1968. Gegronde verwachting: schets van een Christelijke tockomstleer. Nykerk : Callenbach.

BERKOUWER, H 1961. De wederkamsı van Christus. Deel 1. Kampen : Kok (Dogmatiese studienn.).

BINGLE, P W. 1988 Coram Deo: dic betekenis van die eskatologie vir prediking. Potchefstroom. (Proefskrif (Th D.) - PU vir CHO

BOLLNOW, O.F. 1970. Philosophie der Erkenntnis, das Vorverstandnis und die Erfahrung des Neuen. S1utigart: Kohthammer.

CALVYN, F. 1986. Institusie van die Christclike godsdiens 1559. Deel II. In Afrikaans vertaal deur H.W. Simpson Potchefstroom : CIBF 
CALVYN, J. 1988. Institusie van die Christelike godsdiens 1559. Deel III. In Afrikaans vertaal dcur H.W. Simpson. Potchefstroom : CJBF.

FIRET, J. 1975. Godservaring in het interim. (In Baarda, T, red Ad interim: opstellen over eschatologic, apocalyptiek en ethiek. Aangeboden aan prof. dr. R. Schippers. Kampen : Kok. p. 208-217.)

FLOOR, L. 1979. Hel gericht van God volgens het Nieuwe Teslament. Amsterdam : Buijten \& Schipperheijn.

HAITJEMA, TH.L. 1956. Theocratie en eschatologie. Een briefwisseling tussen prof. Th.L Haitjema en prof G.C. van Niftrik. Wageningen : Veerman.

KäSEMANN, E. 1960. Anliegen und Eigenarl der paulinischen Abendmahlslehre. (In Exegetische Versuche und Besinnungen. Vol. 1 Goltingen, p. 11-34

LOUW, D. 1984. Tcologie in hoop. Kaapstad : NG Kerk-Uitgewers

MolleR, B.A. 1984. Markus 14:22-26. (In Burger, C.W; Müller, B.A \& Smit, DJ. reds. Riglyne vi Nagmaalsprediking Kaapstad: NG Kerk-Uitgewers. p. 64-71.)

OUISTORP, H. 1955. Calvin's doctrine of the last things. London : Lutterworth

RIDDERBOS, H. 1966. Paulus: ontwerp van zijn theologie. Kampen : Kok.

SCHUITE, R. 1982. Zeit und Ewigkeit. (In Bockle, F.; Hrsq. Enzyklopädische Bibliothek. Christlicher Glaube in moderncr Gesellschaft. Teilband 22. Freiburg : Herder. p. 121-186.)

SMIT, DJ. 1984. Die prediking by die Nagmaal. (In Burger, C.W; Muller, B.A \& Smit, DJ. reds Riglyne vir Nagmaalsprediking. Kaapslad : NG Kerk-Uitgewers. p. 11-36.)

SNYMaN, WJ. 1977. Nuwe en ou dinge: 'uil die skat van die koninkryk'. Potchefstroom : Pro Rcge.

VAN DER WALT, J.J. 1976. Christus as Hoof van die kerk en die presbiteriale kerkregering. Potchefstroom : Pro Rege.

VAN DER WALT, J.J. 1988. Amp en eskatologie. (In Rossouw, P.J, red. Gereformeerde ampsbeskouing Pretoria : NG Kerkboekhandel. p. 217-229.)

VAN DER WALT, T. 1962. Die koninkryk van God - nahy! Eksegetiesc verkennings van die toekomsperspektief van Jesus Christus volgens die geluienis van die sinopticse evangelics. Kampen : Kok

VAN 'T SPIJKER, W. 1980. Hel klassicke avondmaalsformulicr. (In Van 't Spijker, W., Balke, W. Exalto, K. \& Van Driel, L. reds. By brood en beker. Goudriaan : De Groot. p. 363-419.)

VENTER, CJH. 1985. Die Pauliniese paranese in Romeinc 12:1-15:3: 'n eksegetiese studie. Potchefstronm. (Proefskrif (Th D.) - PU vir CHO.)

VERHOEF, P.A. 1973. Eschatological preaching. Joumal of theology for Southerm Africa, (2):23-29, Mar.

VERSTEEG, J.P. 1980. Het avondmaal volgens hel Nieuwe Teslament. (In Van 't Spijker, W., Balke, W., Exalto, K. en Van Dricl, L. reds. By hrood en beker. Goudriaan : De Groot. p. 9-64.)

WAINWRIGHT, G. 1978. Eucharist and eschalology. London: Epworth 
